$2(29) / 2015$

\author{
Lucyna Kopciewicz. \\ Uniwersytet Gdański \\ pedlk@ug.edu.pl
}

\title{
Jan Jakub Rousseau w naturze/ogrodzie? \\ Dyskursy natury we współczesnych odczytaniach feministycznych i posthumanistycznych
}

\section{Summary \\ Jean Jacques Rousseau and his nature/ garden metaphor. \\ Feminist and posthumanist perspectives on discourses of nature}

The $21^{\text {st }}$ century is called 'the biotech age'. We cannot deny the emergence of significant changes in the way we conceive nature and ourselves. The main influence comes from biotechnologies and information science which modify the definition of nature. This article focuses on Rousseau's discourses of nature understood as moral and gendered bases of social order. Feminism and posthumanism significantly challenge these discourses and contribute to the development of postanthropocentric nature seen as a vital network of human and nonhuman agents.

Słowa kluczowe: natura, ogród, równość, porządek społeczny, płeć kulturowa, posthumanizm

Keywords: nature, garden, equality, social order, gender, posthumanism

W XXI wieku, nazywanym wiekiem biotechnologii, badacze społeczni wyraźniej niż kiedykolwiek zainteresowani są „stykiem” świata natury i kultury, a zwłaszcza praktykami wytyczania granic wpływu natury, ideologią natury i procesami naturalizacji świata społecznego. Argumenty „natury” są często przywoływane w dyskusjach związanych z paniką moralną (w Polsce od około dwóch lat doświadczamy paniki moralnej w związku z gender, kwestią praw mniejszości seksualnych i edukacją seksualną). W dyskusjach tych często padają postulaty zgodności z naturą, powrotu do normalności czy „naturalnego porządku rzeczy". Można się zatem spodziewać większego zainteresowania klasyczną myślą przedstawicieli naturalizmu (jednym z nich jest Jan Jakub Rousseau) i jego centralną kategorią - naturą. Jednak natura nie ma dobrej passy w naukach społecznych, zwłaszcza od lat 70-tych XX wieku. Koncepcja natury zasilała większość przerażających projektów eugenicznych realizowanych podczas II wojny światowej. Z kolei emancypacyjne ruchy społeczne końca lat $60 \mathrm{XX}$ wieku, a później zyskujący na sile konstruktywizm w naukach społecznych, odkrywały nienaprawialne „skażenie” natury, w imię której usprawiedliwiano wyzysk, opresję, nierówności społeczne (koncepcja różnic naturalnych ,powtórzonych” i utrwalonych w kulturze w postaci „oczywistych” hierarchii, nierównych 
możliwości i różnic władzy). Badacze społeczni i teoretycy dowodzili ideologiczności procesów naturalizacji, w których arbitralna historia społeczna zyskiwała status oczywistego, niepodlegającego dyskusji porządku rzeczy (por. R. Barthes 2008).

Celem niniejszego tekstu jest próba identyfikacji znaczeń natury pojawiających się w pismach Rousseau. W drugiej części artykułu odniosę się natomiast do współczesnych dróg problematyzacji pojęcia natura, odwołując się do feministycznego i posthumanistycznego zaplecza teoretycznego.

Jan Jakub Rousseau (1712-1778) jest jednym z najważniejszych przedstawicieli naturalizmu. Początkiem jego twórczości jest powodzenie literackie i pierwsza nagroda w konkursie ogłoszonym przez Akademię w Dijon Discours sur les sciences et les arts (1750), w którym Rousseau zaprzeczał wartości cywilizacji dla rozwoju ludzkości, głosząc dobrodziejstwa stanu naturalnego. Rousseau jest autorem wielu pism polityczno-społecznych (np. Umowa społeczna, Emil, czyli o wychowaniu), które wzbudzały zainteresowanie (Rousseau był czytany przez Goethego, Kanta czy Hume’a), wzmacniały mobilizację polityczną (dzieła Rousseau były czytane podczas Rewolucji Francuskiej koncepcje suwerenności ludu, woli powszechnej itp.), ale też spotykały się z potępieniem władz uniwersyteckich (np. Umowa społeczna i Emil zostały potępione przez Radę Genewy, Emil - potępiony przez paryską Sorbonę oraz francuski parlament). W twórczości Rousseau niejednokrotnie pojawiają się motywy prześladowań, osamotnienia, odrzucenia czy ostracyzmu. Mają one solidne umocowanie biograficzne - wiążą się z prześladowaniami o charakterze politycznym (w następstwie publikacji jego pism pojawiały się nakazy aresztowania autora, zdarzały się konfiskaty opublikowanych książek oraz ich publiczne palenie - co spotkało np. Emila), wiążą się z doświadczeniami wygnania, ucieczki i poszukiwania bezpiecznego miejsca do życia, ale też z zaburzeniami psychicznymi, na które cierpiał Rousseau.

Myśl Rousseau jest odczytywana jako projekt konsolidacji tego co społeczne i tego co moralne poprzez reformy o charakterze społecznym, politycznym i edukacyjnym. Kluczowym konceptem wiążącym społeczeństwo i moralność jest natura. W pismach Rousseau pojawia się ona w kilku odsłonach, pełniąc kilka istotnych funkcji organizujących linię argumentacyjną autora. W niniejszym tekście ograniczę się do dwóch najistotniejszych warstw rozumienia natury. Pierwsza warstwa wiąże się z naturalną różnicą płci, a zwłaszcza koncepcją kobiecości uosabiającą ową naturalną różnicę. Druga warstwa dotyczy natury jako „wewnętrznego głosu”, odnosząc się do ekspresji i artykulacji jaźni. Odniosę się również do spoiwa zidentyfikowanych koncepcji - metafor „ogrodowych”, które ujawniają tęsknotę Rousseau do natury w odpowiedni sposób „przyciętej” i poddanej ludzkim potrzebom. Ogród stanie się następnie punktem wyjścia dla współczesnych rozważań o wizjach zcyborgizowanego Edenu, w których to rozważaniach ujawnia się szereg przesunięć dotyczących znaczeń i roli natury. Nie jest to jednak analiza rekonstrukcyjna, ujawniająca wymiary polemiki ze stanowiskiem Rousseau. Raczej idzie o nakreślenie pewnego pola problemowego, którego kształt współtworzyli naturaliści. 


\section{Naturalna różnica płci}

Jan Jakub Rousseau jako teoretyk państwa i społeczeństwa obywatelskiego w wielu swoich pracach niejednokrotnie przywołuje obraz kobiet, kreślony w niezwykle protekcjonalny sposób. W V księdze Emila czy Liście o widowiskach przedstawia kobiety jako istoty z natury płoche, czcze, puste, słabe fizycznie i intelektualnie. Kobiety, zdaniem Rousseau, są pozbawione prawdziwego geniuszu, ich pisma „nigdy nie będą zawierać niebiańskiego ognia rozpalającego duszę. Kobiety nie potrafią odczuwać miłości” (Rousseau 1966: 454). Esencjalistycznie ujmowane cechy kobiece definiują w przypadku Rousseau „różnicę gatunkową", sugerując radykalną odmienność, a dokładniej - naturalny deficyt. Koncepcja naturalnej różnicy płci pełni u Rousseau istotną rolę organizującą jego projekt społeczno-polityczny (utopię polityczną) i wizję nowego ładu. Krytykując pomysł otwarcia teatru w Genewie, Rousseau przywołuje próżność i małość kobiet jako synonim upadającej kultury politycznej. Kobiecość łączy wyraźnie z groźbą dewaluacji męskości, a ta ostatnia jest dla niego kwintesencją polityczności. Republikańskość i obywatelskość są bowiem istotowo związane z męskością. Z tego też względu esencjalistyczna koncepcja kobiecości wskazuje na sferę nieuchronnych wykluczeń - naturalnej niezdolności do osiągnięcia przez pewne grupy (symbolizowane przez kobiety) właściwego dla obywatela poziomu moralnego. Kobiety, zdaniem Rousseau, przeznaczone są do zamkniętej sfery domowej, a próby wyjścia z niej kończą się dla wspólnoty katastrofą: „Idźmy za wskazówkami natury, miejmy na względzie dobro społeczeństwa, zobaczmy że przedstawiciele obu płci powinni niekiedy się spotkać, a żyć zazwyczaj osobno" (Rousseau 1966: 451). Katastrofalne skutki dla wspólnoty polegają zaś na odzieraniu mężczyzn z moralności i polityczności, na uczynieniu ich podobnymi do kobiet „,nie godząc się na rozstanie, kobiety upodabniają nas do siebie, bo nie mogą upodobnić się same do mężczyzn”; „Ta ujemna strona naszego przebywania razem, tak poniżająca mężczyznę, występuje wszędzie bardzo mocno, szczególnie jednak należy jej zapobiegać w państwach takich jak nasze. Monarsze musi być to dość obojętne, czy rządzi mężczyznami czy kobietami, byleby miał posłuch; lecz Republice trzeba mężczyzn" (tamże).

Republika opisywana w pismach politycznych Rousseau takich, jak Umowa społeczna, List o widowiskach czy w powieści Nowa Heloiza jest tworzona przez ludzi zjednoczonych przede wszystkim moralną suwerennością oraz prostotą obyczajów i organiczną solidarnością. Magdalena Środa przekonuje, że republika Rousseau to surowa holistyczna jedność moralności, celów, poczucia wartości, gdzie „ja” buduje się na poczuciu „my” (Środa 2003: 321). Więzi, które łączą wspólnotę to nie abstrakcyjne prawa i zasady, ale uczucia i obowiązki, których spoiwem jest republikańska cnota. Paradygmatem owej wspólnoty idealnej była mała góralska wioska (z okolic Neuchatel) zagrożona ze strony zgubnych wynalazków cywilizacji takich, jak na przykład siejące zgorszenie teatry (Rousseau 1966: 402). W sposobie portretowania owej wioski uderza osobliwe połączenie wyidealizowania i sentymentalizmu w ujęciu organicznej solidarności ludzkiej z „,zimną" i jednoznacznie przejrzystą strukturą społeczną i podziałami, które zyskują wzmoc- 
nienie ze strony moralnych cnót i praktyk, blokujących wszelkie potencjalne dążenia do niezależności i indywidualnej wolności (Środa 2003: 73). Owa organiczna, quasi-naturalna wspólnota posiada zaskakująco efektywną zdolność odtwarzania struktury ról jej członków oraz dyskursów lokujących owe podziały w szerszych koncepcjach spójności społecznej. Rousseau w sielankowych opisach perfekcyjnego dopasowania i harmonijnej koegzystencji ludzi umiejscowił twarde struktury nierówności, separacji i segregacji. Z punktu widzenia pryncypiów współczesnych demokracji ten sposób konceptualizacji natury jest bardzo groźny. Zapowiada bowiem nieuchronność wykluczeń, których domaga się sama ,natura”.

Potencjał wykluczeń bardzo wyraźnie uwidocznia się w Emilu. W tym traktacie o wychowaniu naturalnym Rousseau sportretował prototypową dziecięcą parę - Emila i Zofię, w którym jedynie Emil jest dzieckiem prawdziwym (w Zofii owej dziecięcości jest mniej) przez niepokonywalną różnicę ich płciowej natury. Mężczyzna, zdaniem Rousseau, musi być czynny i silny, kobieta - bierna i słaba: ,jest koniecznością, aby mężczyzna chciał i mógł, wystarczy aby kobieta nieco się wzbraniała. Kobieta jest to po, by podobać się mężczyźnie" (Rousseau 1955: 220). Inna postać wykluczeń dotyczy potencjalnej aktywności intelektualnej chłopców i dziewcząt: „Badanie prawd abstrakcyjnych i spekulatywnych, zasad i aksjomatów naukowych, słowem wszystkiego, co stanowi uogólnienie pojęć, nie jest zajęciem dla kobiet. Myśl kobiety we wszystkim co nie dotyczy bezpośrednio jej obowiązków, powinna się ograniczyć do studiów nad człowiekiem lub wiadomości przyjemnych" (tamże: 265).

Do pierwszych feministycznych reakcji na pisma Rousseau trzeba zaliczyć pracę Mary Wollstonecraft, opublikowaną w 1792 roku (A Vindication of the Rights of Woman; w polskim przekładzie: Wołanie o prawa kobiety). Autorka polemizując z Rousseau, dowodziła, że proponowany przez niego wyidealizowany stereotyp kobiecości prowadzi kobiety wprost do zniewolenia i podporządkowania mężczyznom. Tymczasem warunkiem zaistnienia prawdziwego społeczeństwa obywatelskiego jest emancypacja kobiet, zaś drogą emancypacji - edukacja. Bóg, jak pisze Wollstonecraft, wyposażył wszystkich ludzi w rozum po to, by kształcili w sobie cnoty i używając rozumu osiągali szczęście. Jej zdaniem, brak edukacji powodował, że kobiety były skazane na posługiwanie się emocjami i rozwijały w sobie imperatyw przypodobania się mężczyznom, od których w pełni zależał ich los. Pozbawianie kobiet racjonalnego doskonalenia własnej natury uczyniło je łagodnymi, domowymi zwierzętami: niemądrymi, nastawionymi na przyjemności, słabymi, delikatnymi i bez charakteru. Natomiast wykształcona, racjonalna kobieta byłaby - w opinii autorki - ostoją rodziny i porządku społecznego (Wollstonectaft 2011). Wollstonecraft jako jedna z pierwszych zauważyła, że tak zwana „kobieca natura” jest efektem zachowawczej socjalizacji i braku wartościowej edukacji. Z wielką niechęcią i nieufnością odnosiła się zatem do katalogu tak zwanych „,cnót kobiecych”, których teorię rozwinął Rousseau w drugiej części Emila. 


\section{Natura jako wewnętrzny głos}

Drugi z Rousseańskich dyskursów natury wiąże się z koncepcją wewnętrznego głosu jako źródła postępowania moralnego. Rousseau dokonuje w tym przypadku dowartościowania i upełnomocnienia sfery uczuć, prywatności, intymności, wysuwając na pierwszy plan możliwość wyrażania własnej oryginalności. Wewnętrzny głos jest drogą samopoznania i kształtowania własnej tożsamości. W koncepcji tej daje się również wyczytać swoista „troska o siebie” jako podstawa tożsamościowego projektowania ,ja”. Wskazane pole dyskursywne ma niewątpliwy związek z biograficznymi kontekstami: ostracyzmem, osamotnieniem, buntem, poczuciem odrębności, inności i odrzucenia oraz dążenia do podkreślania owej inności, z którymi zmagał się Jan Jakub Rousseau.

Rousseańskie rozumienie natury nie opiera się tu jednak na żadnej tezie empirycznej. Magdalena Środa zwraca uwagę, iż natura u Rousseau pełni w większej mierze funkcje idealistyczne niż heurystyczne. Natura odnosi się do tego, co utracone lub ukryte. Jest celem, wzorem, czymś do czego nie zawsze można powrócić jak do źródła, ale co można stworzyć w procesie tworzenia siebie (Środa 2003: 69). Natura jest tu bowiem utożsamiona z koncepcją wewnętrzności istotnej z punku widzenia nowożytnej koncepcji jaźni. Natura jest wewnętrznym głosem odkrywającym dobro; głosem, który łączy nas ze światem (Taylor 2001: 667).

Dla oświeceniowych naturalistów uczucia moralne stanowiły istotne źródło rozumienia dobra. Trafność uczuć moralnych zależała jednak od tego, na ile lokowały się one w harmonii świata lub opatrznościowym ładzie. Do takiej koncepcji ładu odnosił się również Rousseau wskazując, że ostatecznym szczęściem człowieka jest życie zgodne z głosem natury, czyli bycie w pełni sobą. Pojęcie wewnętrznego głosu natury jest jednak wyrazem czegoś bardziej istotnego i silniejszego, bowiem ów głos ma moc pokonywania rozdźwięku między prawdziwą „naturą” a pełną pozorów, niesprawiedliwości i upadku „kulturą" (Środa 2003: 70). To, co istotne, tkwi zatem wewnątrz człowieka i tylko wewnątrz pozostaje czyste. W rękach człowieka wszystko ulega spaczeniu. Niemniej jednak wewnętrzny głos to nie tylko ekspresja wewnętrzności. Głos ów może być rozumiany jako sumienie - uczucia moralne pozostające $\mathrm{w}$ harmonii $\mathrm{z}$ dobrem ogólnym: wewnętrzność u Rousseau jest bowiem tożsama z dobrem. Wewnętrzny głos można też rozumieć jako głos serca, obejmującego to, co istotne i poznającego to, co istotne w głębi autentycznych ludzkich uczuć. Innymi słowy, w ten sposób poszerzony „głos” (sumienie, serce) ma szansę przebić społeczną grę pozorów, konformizmu i zepsucia.

Koncepcja wewnętrznego głosu jest mocno związana $\mathrm{z}$ wątkami samotności, ostracyzmem i niezrozumieniem, z którymi konfrontowany był Rousseau. Jak przekonują znawcy jego biografii, ucieczka Rousseau przed społeczeństwem miała różne przyczyny. Jedną z nich mogła być psychoza, kłopoty w kontaktach z ludźmi oraz poczucie prześladowania, które pchnęły go do poszukiwania świata własnej autentyczności (Śniedziewski 2011).

Przechadzki samotnego marzyciela są najbardziej wyrazistym i poruszającym zapisem psychozy Rousseau. Rousseau czuje się zaszczuty, opuszczony przez wszystkich. 
Nic więc dziwnego, że pierwsza przechadzka rozpoczyna się od słów: „Tak więc jestem na ziemi sam, skazany na własne tylko towarzystwo, bez brata, bliźniego, przyjaciela. Za zgodą wszystkich został wykreślony spomiędzy ludzi najbardziej z nich towarzyski, najbardziej kochający człowiek" (Rousseau 1967: 3). Samotność Rousseau nie wynika z wyboru, mimo że nieustannie podkreśla, że jest stworzony do życia na marginesie. W Wyznaniach przyznaje, że „bezczynność towarzystw jest zabójcza, ponieważ jest musowa; bezczynność samotności jest urocza, ponieważ jest swobodna i dobrowolna" (Rousseau 1956: 498). Jednak, jak sam twierdzi, nie on wybrał samotność, ale został do niej zmuszony przez zawistnych ludzi, dawnych przyjaciół, fałszywych protektorów - temat spisku nieustannie przewija się zarówno przez Wyznania, jak i Przechadzki samotnego marzyciela (jest ofiarą ,powszechnego spisku”). Człowiek, który ,jest na ziemi sam”, skazany na własne towarzystwo może się poświęcić się obserwacji własnej duszy: „samotny na resztę mych dni, bo tylko w sobie samym znajduję pociechę, nadzieję i ukojenie, nie mam obowiązku ani zamiaru zajmować się niczym poza sobą. Ostatek życia poświęcam obserwowaniu samego siebie i przygotowaniu z góry rozliczenia, jakie mi przyjdzie niedługo przedstawić. Oddajmy się więc w pełni rozkoszy, jaką niesie rozmowa z własną duszą, bo jej tylko nie zdołają mi odebrać ludzie" (Rousseau 1967: 9-10).

Jednak autorzy, którzy ze sceptycyzmem odnoszą się do możliwości odczytań Rousseau w perspektywie biograficznej, a zwłaszcza trapiących go psychoz (Baczko 2009), wskazują, że pojęcie autentyczności wiąże się ściśle z kategorią ekspresji i jest istotne dla podstaw indywidualizmu (Baczko 2009). Indywidualność nie wyraża się poprzez powielanie czy odtwarzanie. Indywidualność nie ujawnia się, ale stwarza poprzez uczucia i ich akty. Jak zauważa Środa: ,ja” odkrywa się i jednocześnie wchodzi w posiadanie siebie. $\mathrm{Z}$ tą samą chwilą poddaje w wątpliwość wszystko, co sądziło lub wiedziało o sobie (Środa 2003: 72). Spełnienie własnej natury polega na otworzeniu się na wewnętrzny pęd życia lub impuls, na ujawnianiu przed sobą i innymi tego, co było ukryte. Ujawnienie polega jednak na określeniu tego, co powinno zostać zrealizowane. Zdaniem Charlesa Taylora koncepcja ekspresji jako artykulacji zarówno ujawniającej jak i nadającej życiu kształt powstaje w czasach nowożytnych i właśnie dzięki Rousseau (Taylor 2001: 694). Wyrażanie własnej oryginalności bazuje na przekonaniu o konieczności opuszczenia pozorów i hipokryzji właściwych życiu społecznemu, w obrębie którego nawet najostrzejsza krytyka byłaby fikcją (Środa 2003: 73). Zatem pierwszym krokiem odzyskania siebie jest ustawienie się na zewnątrz, poza społeczeństwem. Skoro bowiem zło zamieszkuje w granicach świata społecznego i pokrywa się z jego granicami, to opuszczenie świata społecznego sprzyja staniu się „piękną duszą". Pojęcie pięknej duszy, do którego odwoływał się Rousseau, przywodzi na myśl ideę estetyzacji życia (niedojrzała koncepcja życia jako dzieła sztuki). Zatem akty wyrażania własnej oryginalności można odczytywać jako próbę zniwelowania granic dzielących to, co etyczne i to, co estetyczne. Indywidualizm ekspresyjny może oznaczać artykulację autentyczności, bez granic pomiędzy pięknem a dobrem: tym co trwałe i tym co zmienne. Jak przekonuje Środa, w ten sposób konstruowana tożsamość nie osiąga żadnej trwałości ani regularności (tamże: 74). 


\section{Natura czy ogród?}

W Rousseańskich opisach natury zastanawiać musi zabieg rozłożenia akcentów: Rousseau koncentruje się wyłącznie na pozytywnych aspektach natury. Natura w jego pismach jest portretowana jako domena harmonii: jest piękna, nienaruszona i niewinna. Wydaje się, że jest opisywana raczej statycznie niż dynamicznie, z wyraźnie ocenzurowanymi wątkami, które mogłyby przywodzić na myśl jej bezwzględność czy okrucieństwo. Może się wydawać, że w Rousseańskiej koncepcji natury przemawia narcystyczna projekcja wynikająca z potrzeby ładu, bezpieczeństwa i komfortu: „Przepyszne kwiaty, różnobarwność łąk, chłodne cienie, strumienie, gaje, zieleni przybywajcie [...]" (Roussaeu 1967: 125). Stabilna i bezpieczna przyroda jako zewnętrzny układ odniesienia ma dostarczać wewnętrznego poczucia sensu: „Nie, próżne argumenty nie zniszczą nigdy zgodności, którą dostrzegam między moją nieśmiertelną naturą a układem tego świata i porządkiem fizycznym, który, jak widzę, w nim panuje. W odpowiadającym mu porządku moralny, którego system jest rezultatem moich poszukiwań, znajduję oparcie, niezbędne mi, bym mógł znosić niedole swego życia" (tamże: 57).

Natura jest raczej pomyślana jako „dziewiczy ogród”. Na pierwszy rzut oka natura sprawia bowiem wrażenie nietkniętej ludzką ręką. Niemniej jednak jest w całości efektem nieustannych zabiegów i ingerencji, porządkujących ją zgodnie z zamysłem ogrodnika.

$\mathrm{Na}$ nagromadzenie metafor sielsko-ogrodowych natkniemy się zwłaszcza w Emilu, który jest traktatem o „naturalnym wychowaniu”. W tym przypadku mamy do czynienia z serią dyskursywnych przesunięć: „naturalne sytuacje” wychowawcze są tu wyraźnie aranżowane przez wychowawczą władzę, zachowującą niski (niemal niewidoczny) profil.

Rousseau jako wielki moralizator swoich czasów eksperymentował na sobie, by zrealizować projekt konsolidacji tego, co moralne i społeczne. Samotność i to, co się w niej wyrażało, służyły mu również do wyraźniejszej ekspresji własnej jaźni. Dla jej artykulacji mniej ważne były społeczne cele, w imieniu których występował. Ważniejszy był projekt tworzenia samego siebie poprzez swoją twórczość. Choć koncepty takie, jak wola powszechna, stały się niewątpliwie pożywką rewolucji francuskiej, to nie mniej ważnym projektem okazała się ekspresja/konstrukcja własnej indywidualności i oryginalności. Intymność, prywatność, wewnętrzność, nieokreśloność, zmienność jaźni oraz uczucia, które tworzą własny świat, i które nie stanowią przeszkody w poznawaniu rzeczywistości, w projekcie Rousseau docierają do prawdy skuteczniej niż wola powszechna (Środa 2003: 75). Jak twierdzi Taylor, od Rousseau zaczyna się transformacja nowoczesnej kultury zmierzająca w kierunku afirmacji wewnętrzności i artykulacji różnic (Taylor 2001: 692), które to procesy są kluczowe dla współczesnych społeczeństw demokratycznych. Ta część dorobku Rousseau wydaje się warta obrony, z bardzo istotnym zastrzeżeniem: współczesne pole dyskursu natury bardzo się komplikuje. Owo skomplikowanie zostanie omówione w drugiej części tekstu. 


\section{„Naturakultura”. Inspiracje feministyczne}

Feministyczne interpretacje Rousseańskich dyskursów natury są odczytaniami demaskującymi obszary ukrytych znaczeń, mechanizmów i procesów deponowanych przez autora w konstrukty natury. Krytyka tego pojęcia z pozycji feministycznych pozwala na przyjrzenie się funkcjom, które przepisuje naturze Rousseau: poczynionym przez niego zabiegom ideologizowania natury, mającym służyć „,elom wyższym” - konstytuowaniu nowego porządku społecznego bądź umożliwieniu samopoznania.

Feminizm można zatem nazwać demaskatorskim typem refleksji, odkrywającym polityczność dyskursów natury. Jednak w wielu nurtach feminizmu kategoria natury zachowuje istotność w perspektywie politycznej i społecznej: ma być punktem wyjścia dla projektów kulturowej zmiany. Kategoria natury jest najwyraźniej eksplorowana w ekofeminizmie, na gruncie którego uznaje się, iż patriarcha logika dominacji jednym gestem spycha na margines to, co kobiece i to, co naturalne: feminizując naturę i naturalizując kobietę. Ekofeminizm jest strategiczną koalicją kobiet ze środowiskiem naturalnym, która ma na celu walkę z destrukcyjnym kapitalizmem, militaryzmem i innymi strukturami dominacji (Fedorczuk 2015: 167). Pierwszym krokiem w procesie kulturowych zmian jest kontestacja hierarchicznych dualizmów (np. natura/kultura, ciało/dusza), na których wspiera się zachodnia cywilizacja. Drugim - tożsamościowe rekonstrukcje zmierzające do zastąpienia filozofii dominacji i podporządkowania etyką troski i współdziałania, zaś trzecim krokiem działania na rzecz płynnych tożsamości, uznania rozmaitości więzi międzyludzkich i przenikani się różnych form życia na ziemi. Ostatnie ze stanowisk (właściwe feminizmowi posthumanistycznemu) kontestuje obowiązujące ontologie i wynikającą z nich normatywność (tamże: 180).

W obecnych postkonstruktywistycznych czasach teoria i praktyka feministyczna jest coraz poważniej uwikłana w posthumanizm, co oznacza że jej emancypacyjne cele ulokowane są w kontekście szerszej koncepcji zmiany, nie zaś drobnych korekt społecznych, czyniących pozycję kobiet korzystniejszą w ramach istniejącego układu sił. Drogi tego uwikłania wiodą od najważniejszego teoretycznego narzędzia feminizmu, jakim jest definicja płci kulturowej (kulturowa interpretacja różnicy płci - gender), a ściślej, od sposobów interpretacji znaczenia gender. Dwa najistotniejsze sposoby interpretacji gender wywodzą się z dwóch odmiennych szkół teoretycznych, z których czerpie teoria i praktyka feministyczna - tradycji kontynentalnej (francuskiej) oraz tradycji amerykańskiej.

Tradycja francuska jest bardzo silnie umocowana w poststrukturalizmie, który daje dostęp do analizy abstrakcyjnych mechanizmów władzy wywierających materialne skutki. Ukazała ona, w jak wielkim stopniu instytucje społeczne i struktury naszego myślenia są generowane przez gender (dokonania Lucy Irigaray, Helene Cixous czy Julii Kristevy dotyczące krytyki fallogocentryzmu). Druga z tradycji - tradycja anglosaska, wiązała się z próbą oddzielenia płci biologicznej i płci kulturowej, co otworzyło amerykańską teorię feministyczną na wyrafinowane analizy sposobów, dróg i mechanizmów społecznego konstruowania płci. Emancypacyjny cel feminizmu został w tym przypadku wy- 
raźnie związany ze wzmacnianiem stanowiska konstruktywistycznego (Briadotti 2014: 17). Obie te tradycje inaczej konceptualizują kwestię podmiotowości oraz materialności - zagadnień newralgicznych także dla stanowiska posthumanistycznego (rekonstruowanego w kolejnej części tekstu). Problemy statusu ciała (jego materialności), znaczenia płci i biologizmu, które były długo dyskutowane na feministycznym gruncie, okazały się kluczowe także dla posthumanizmu.

Tradycja kontynentalna inspirująca się w znacznej mierze psychoanalizą nie uznawała, co prawda, esencjalności płci, ale też nie odrzucała analiz tego, co materialne - ciała, pragnień, popędów. Statusu tych ostatnich nie sposób bowiem jednoznacznie przypisać ani domenie natury ani kultury. W tym znaczeniu tradycja ta okazała się mniej wrażliwa na spór esencjalizm - konstruktywizm. Z kolei tradycja amerykańska konsekwentnie ujmowała ciało jako przestrzeń zapisu kulturowych znaczeń i dyspozycji (tamże), odżegnując się od wszelkich aspektów, które mogłyby wywoływać jakiekolwiek skojarzenia z esencjalizmem. Próbą wyjścia feminizmu z ,pułapki esencjalizmu” z jednej strony i konstruktywizmu z drugiej był feminizm korporalny (funkcjonujący niekiedy pod nazwą feminizm ciała) - ideowo zbieżny z posthumanizmem (Hyży 2003). Pojawienie się feminizmu korporalnego nastąpiło w latach 90 -tych XX wieku. Analizy podejmowane przez feministki tej orientacji dotyczyły problematyki materialności i realności ciała - konstruowanego zarówno przez dyskursy jak i praktyki biologii oraz organizację popędów (Braidotti 2014: 20). Stanowisko to nie przekreśliło jednak osiągnięć konstruktywizmu. Oznaczało raczej przeniesienie konstruktywizmu na inny poziom problematyzacji, gdzie krytycznej rewizji został poddany wielki podział, wspierający fundamenty myślowe zachodniej cywilizacji, tj. dychotomię natura - kultura. Jak już zaznaczałam, rozstrzygnięcia dokonywane na gruncie feminizmu korporalnego stanowiły podatny grunt dla współczesnych nurtów takich, jak nowy materializm i posthumanizm. Prace takich feministek jak Rosi Braidotti, Donny Haraway czy Elisabeth Grosz są obecnie uznawane za fundamentalne dla skutecznego demontażu kategorii natury oraz nowego powiązania w ramach materialistycznych ujęć „naturykultury”. Nowa konceptualizacja „naturykultury” przekracza klarowny podział na to, co zostało zrobione i na to, co powstało samo - na aktywne podmioty i pasywne przedmioty, na wolne podmioty ludzkie i kierujące się instynktem zwierzęta czy na sprawczych ludzi wytwarzających społeczeństwo i narzędzia działające dzięki ludzkim rękom. Koncepcja ta pozwala również na porzucenie antropocentryzmu, dzięki czemu możliwe staje się nowe spojrzenie na dyskusję o podmiotowości. Dotychczasowe pole dyskusji o kwestii podmiotu dotyczyło strategii politycznych oraz puli pytań o ich skuteczność. Ogniskowało się wokół kwestii polityki prowadzonej z pozycji podmiotowych (i zdefiniowanej tożsamości) i próbowało się zmierzyć z konstruktywistyczną wizją polityki bez podmiotu, polityki podejmowanej w imię bliżej nieokreślonych strategii solidarności wszystkich „różniących się”. Jednak jedna i druga strategia posiadała nieusuwalne wady. Co bowiem może być podstawą polityki podmiotowej? Liberalny podmiot „bez płci" i uniwersalistyczna etyka (Środa 2003), czy podmiot kobiecy i etyka troski (Gilligan 2015)? Jak z kolei mierzyć skuteczność polityki solidarności? Kogo ona obejmuje 
i w czyim interesie jest podejmowana? Komu służy? Z tymi pytaniami emancypacyjne ruchu społeczne pozostające w okowach sporu esencjalizm versus konstruktywizm nie poradziły sobie do dziś.

Jak przekonuje Braidotti dyskusja o podmiocie może wyglądać inaczej. Ujmując podmiot nieantropocentrycznie i uznając go raczej za splot sił niż zcentrowaną strukturę - byt z definicji relacyjny, będący jedynie efektem związków, w które wchodzi z podmiotami ludzkimi oraz podmiotami innymi niż ludzie, możliwe staje się skuteczne zakwestionowanie granic dzielących poszczególne byty na rzecz myślenia hybrydalnego - myślenia o nieuchronnych powiązaniach, kolektywach i współdziałaniu. Zamiast koncepcji autonomii właściwej odseparowanym od siebie podmiotom, pojawiają się koncepcje zależności - nieuniknionych wpływów wywieranych na życie przez czynniki osobowe i nieosobowe - przyrodnicze, społeczne, historyczne, technologiczne, które to czynniki determinują wszelkie działanie i sprawczość (Braidotti 2014: 25). Pojawia się zatem nowa możliwość ujęcia podmiotów, zawsze w liczbie mnogiej: ,podmiot czyli wspólnota” (Bakke, 2010) jako bytów niepojedyńczych, kolektywnych, współzależnych, o przepuszczalnych granicach, tworzonych przez nieosobowe i heterogeniczne siły, zdolnych do tworzenia międzygatunkowych powiązań (sieci). W tym celu bardzo pomocne mogą okazać się figury współczesności - liminalne życia, hybrydy, chimery i symbionty (Bakke, 2010), organizmy transgenetyczne (Katz za Bakke 2010), cyborginie (Haraway 2003), wskazując czym może być i jak może się realizować współczesna hybrydyzacja. W tej optyce dotychczasowa teoria społeczna, teoria działania społecznego, teoretyzacje dotyczące odmienności i działania politycznego podlegają rekonfiguracji.

Nietrudno zauważyć, że feministyczno-posthumanistyczne zmagania ze statusem materialności i cielesności oddalają nas - i to zdecydowanie - od Rousseańskiego rozumienia natury, z której autor ze wstrętem wykluczył wszystko to, co cielesne oraz to, co wiąże się w jakikolwiek sposób z anatomią czy fizjologią: ,jakże okropny jest widok anatomicznego amfiteatru, cuchnące trupy, oślizgłe, sine ciała, krew, wstrętne wnętrzności, okropne szkielety, trujące opary. Nie, nie tam Jan Jakub będzie szukać rozrywek..." (Rousseau 1967: 124).

Współczesny feminizm i posthumanizm paradoksalnie jednak mają coś wspólnego z Rousseau. To teoretyczne spotkanie następuje w obszarze sygnalizowanej już wcześniej metafory ogrodowej. O ile jednak Rousseau w ogrodzie/naturze szuka schronienia, przyjemności i wytchnienia, o tyle współczesny ogród globalny/planetarny jest miejscem urzeczywistniania się troski o zachowanie bioróżnorodności. Ogród globalny/planetarny jest dynamicznym polem sił witalnych, w którym spotykają się zarówno porządkujące zabiegi ogrodników, jak i witalizm wszelkiego życia podlegającego ewolucji. Są to więc zarówno „przepyszne kwiaty i gaje” (nawiązując do terminologii Rousseau), jak i chwasty oraz wszystkie inne elementy przyrody ożywionej i nieożywionej. Chodzi więc, metaforycznie rzecz ujmując, o przestrzeń, w której skutki ludzkich działań spotykają się z zawsze nieprzewidywalnym działaniem dzikiej przyrody, tworząc hybrydalną (cyborgiczną) jakość (Fiedorczuk 2015: 196). Ów cyborgiczny ogród nie czerpie swojej żywotności 
z idei czystości (np. gatunkowej) i gestu rozdzielania (np. „zieleni” od „sinych ciał”, jak w przypadku Rousseau), ale z przesuwania granic, „międzykategorialności” i hybrydyzacji; innymi słowy z przybierającego współcześnie na sile ruchu łączenia bios i techne.

\section{Posthumanizm}

XXI wiek został ogłoszony wiekiem biotechnologii, co w kontekście teorii społecznej pociągnęło za sobą szereg istotnych zmian w myśleniu o tym, kim jesteśmy wobec nie-ludzkich form życia oraz technologii (Bakke 2010: 7). Posthumanizm wyrósł na gruncie krytycznych teorii społecznych (przykład tego zwrotu został przedstawiony wyżej w odniesieniu do feminizmu), ale jest również znacząco zasilany przez nauki przyrodnicze i informatyczne, które interesują się materią życia. Nicolas Rose opisując współczesność zwraca uwagę, że jesteśmy w centrum istotnego kulturowego procesu, który niepostrzeżenie prowadzi do szeregu transfiguracji, dzięki którym zaczynamy dostrzegać liczne powiązania, zależności i ciągłość w miejscach, w których uprzednio dostrzegaliśmy wyłącznie granice (Rose 2011).

Do najistotniejszych konsekwencji związanych bezpośrednio z zaistnieniem posthumanizmu należy zbiór pytań o status człowieka wobec nie-ludzkich form życia oraz artefaktów. O ile panuje zgodna odnośnie do faktu utraty przez człowieka wyróżnionego (szczególnego czy nadrzędnego) statusu, o tyle poszczególnych autorów różni interpretacja tego faktu. Niektórzy głoszą zatem „kres człowieka”, wiążąc go z dynamicznym postępem biotechnologii i technologii cyfrowych, wskazując, że cyborg (ulepszony technologicznie człowiek-maszyna) lub postczłowiek stanie się nowym normatywnym „punktem docelowy” stechnicyzowanego rozwoju (More 2014). Inni z kolei podtrzymują koncepcję „człowieka zdecentrowanego” (przemyślanego poza konceptualną ramą antropocentryzmu) - organizmu ulokowanego w sieci witalnych współzależności z nie-ludzkimi formami życia i technologiami (Bakke 2010: 8). Warto jednak zaznaczyć, że człowiek jako taki nie znika z horyzontu refleksji społecznej czy filozoficznej, ale niewątpliwie zanika uprzywilejowana pozycja ludzka, wyróżniana ze względu na kryteria przynależności gatunkowej. Intensyfikacja dyskursu posthumanistycznego postępująca wraz z dynamicznym rozwojem biotechnologii oraz technologii cyfrowych ma niebagatelny wpływ na sposób, w jaki ujmuje się samo życie i jego przebieg. Technologie cyfrowe, postępy farmakologii, inżynieria genetyczna, biologia molekularna wyraźnie sprzyjają kwestionowaniu na to, co powstało samo (natura) i na to, co zostało zrobione (kultura). Jednocześnie liczne bio-transfiguracje (na przykład działania związane z modyfikowaniem genomów, których efektem jest istnienie organizmów transgenicznych) czy technologiczne nadzieje pokładane w skonstruowaniu lepszego ludzkiego wcielenia - „wtopienia się” ludzi w świat rzeczy (życie in silico) sprzyjają włączeniu nie-ludzkich innych (zwierząt i przedmiotów) w domenę sprawczości (działania społecznego) oraz domenę etyki. Jak już zaznaczałam wcześniej, posthumanizm w swych licznych orientacjach (biokonserwatywnej lub transhumanistycznej) i odczytaniach (optymistycznych i pesymistycznych) kwestio- 
nuje dogmatyczne podziały funkcjonujące w obrębie zachodniej myśli społecznej dotyczące aktywnie działających podmiotów (ludzi) i pasywnych przedmiotów, komplikując pojęcie sprawczości i obejmując nim podmioty inne niż ludzie. Jednym z najciekawszych przykładów takiego ujęcia jest teoria aktora-sieci. Latourowska teoria jest stosunkowo dobrze opisana $\mathrm{w}$ literaturze polskojęzycznej, zatem odniosę się do jej najważniejszych elementów. Jej najistotniejszym posthumanistycznym rysem jest uznanie relacyjności bytów, ich egzystowania w relacjach oraz definiowania ich właściwości, atrybutów czy cech nie w esencjach (,stabilnych naturach”), ale w synergii - nabierania różnych właściwości (atrybutów czy cech) w heterogenicznych sieciach łączących różne rodzaje materiałów i bytów. Jak wskazuje Latour, rzeczywistości nie da się odnaleźć w esencjach, ale w połączeniach i mieszaninach, w kłączach kultury i natury, gdzie ludzie i nie-ludzie pozostają w bliskich relacjach kooperacji. Stąd właściwości, atrybuty i esencje wynikają jedynie z efektu włączenia w określoną sieć, skąd oddziałują na pozostałe jej elementy (Latour 2011). Neomaterialistyczny rys teorii Latoura ujawnia się również w założeniach dotyczących działania społecznego: sprawczym aktorem i aktantem mogą być zarówno rzeczy, ludzie oraz istoty nie-ludzkie. Latour kreśli zatem radykalnie nowy porządek demokratyczny, który nikogo nie pomija w sieciach społecznego sprawstwa, który nikogo i niczego nie wyklucza, gdyż wszystko jest częścią jakiejś sieci i wszystko jest włączone w określony program działania. W tym znaczeniu posthumanizm, a w jego ramach neomaterializm, można określić mianem nowej teorii politycznej, której istotą jest poszerzona koncepcja demokracji obejmująca podmioty inne niż ludzie (Olsen 2010: 592).

W tym miejscu można zadać pytanie o związki indywidualistycznych koncepcji demokracji (u Rousseau) i demokracji obejmującej podmioty inne niż ludzie (u Latoura). Nowoczesny indywidualizm ekspresyjny właściwy romantyzmowi powstał w specyficznym momencie historycznym. Latour zauważył, że nowożytność uznano za początek i tryumf humanizmu, za ,narodziny człowieka" i podmiotu. Utrzymuje on jednak, że przemilczanym aspektem tego procesu są narodziny nie-człowieka, narodziny rzeczy, czyli przedmiotów i zwierząt, uznanych za coś fundamentalnie odmiennego od ludzi (Latour 201: 13). W tym znaczeniu Latourowska koncepcja demokracji demaskuje i przekracza romantyczno-naturalistyczną bazę.

Posthumanistyczne pytania o życie, ujmowane poza ramą dogmatycznych dla zachodu opozycji natura - kultura, ludzkie - nie-ludzkie, żywe - martwe nawiązują do tradycji etycznych wypieranych przez tradycyjną humanistkę. Posthumanizm jest więc również próbą nakreślenia propozycji etycznej konstruowanej z pominięciem antropocentryzmu. Na szczególną uwagę zasługuje w tej perspektywie koncepcja Rosi Braidotti, afirmująca zoe - generatywną witalność pozaludzkiego i przedludzkiego życia (Braidotti 2006: 37), toczącego się niezależnie i bez względu na racjonalną kontrolę. Koncepcja Braidotti jest utrzymana w duchu neomaterialistycznym: jest to koncepcja witalistyczna i egalitarna. Nie jest ona typem relatywistycznej czy nihilistycznej koncepcji etycznej. Jej istotą jest materialistyczne ujęcie podstaw życia wcielonego i symbiotycznie powiązanego z innymi ciałami (Bakke 2010: 88). Życie w egalitarnym sensie (każde życie), toczy się bez wzglę- 
du na indywidualne śmierci, mnoży się wszędzie w intensywności i wielości form. Nie jest ono pozbawione przemocy, ale jest też głęboko współczujące. Zatem toczy się zawsze na krawędzi życia i śmierci. Mimo, iż konkretne, indywidualne organizmy giną, życie (zoe) wciąż trwa. Wraz ze swoją dynamiką rozmnażania, odżywiania, fuzji, infekowania, umierania lub zabijania zoe rozgrywa się poza moralnymi wyborami i decyzjami jednostek. Nie ma zatem, jak przekonuje autorka, ,istotnej różnicy między złośliwym namnażaniem się komórek nowotworowych, a łagodnym namnażaniem się komórek w czasie ciąży. Życiu nieuchronnie towarzyszą śmierć i nieśmiertelność” (Braidotti 2006: 223).

Rozważania o naturze zaproponowane w niniejszym tekście zapoczątkowała teza o konsolidacji tego co społeczne i tego, co moralne. Natura stała się spoiwem owego projektu oraz wyidealizowanym wzorem pewnego porządku społecznego, w który wpisano supremację męskości lub ekspresję indywidualnej oryginalności. Analizowanie sposobów konstruowania natury i jej funkcji pełnionych wobec tego, co społeczne zaowocowało powstaniem nieantropocentrycznych koncepcji polityki i etyki, których istotą (w obszarze teorii i praktyki społecznej) jest próba poszukiwania pozytywnych, produktywnych sposobów zrównoważonego współistnienia, współdziałania i wymiany zachodzących między istotami nie-ludzkimi, ludźmi i przedmiotami.

\section{Literatura}

Baczko B. (2009), Rousseau: samotność $i$ wspólnota. Gdańsk, Wydawnictwo słowo/obraz terytoria. Bakke M. (2010), Bio-transfiguracje, Sztuka i estetyka posthumanizmu. Poznań, Wydawnictwo Naukowe UAM.

Barthes B. (2008), Mitologie. Warszawa, Aletheia.

Braidotti R. (2006), Transpositions: on nomadic ethics. Cambridge, Polity Press.

Braidotti R. (2014), Po człowieku. Warszawa, PWN.

Fiedorczuk J. (2015), Cyborg w ogrodzie. Wprowadzenie do ekokrytyki. Gdańsk, Wydawnictwo Naukowe KATEDRA.

Gilligan C. (2015), Innym głosem. Teoria psychologiczna a rozwój kobiet. Warszawa, Wydawnictwo Krytyki Politycznej.

Haraway D. (2003), Manifest cyborgów: nauka, technologia i feminizm socjalistyczny lat osiemdziesiątych. „Przegląd Filozoficzno-Literacki” nr 1.

Hyży E. (2003), Kobieta, ciało, tożsamość. Kraków, UNIVERSITAS.

Latour B. (2009), Polityka natury. Warszawa, Wydawnictwo Krytyki Politycznej.

Latour B. (2011), Nigdy nie byliśmy nowocześni. Warszawa, Oficyna Naukowa.

More M. (2014), The extropian priniciples. A transhumanist declaration, http://vency.com/EXtropian3.htm (dostęp 30.12.2014)

Olsen B.(2010), Kultura materialna po tekście: przywracanie obecności rzeczom. W: E. Domańska (red.), Teoria wiedzy o przeszłości na tle współczesnej humanistyki. Poznań, Wydawnictwo Poznańskie.

Rose N. (2011), Polityka życia samego. „Praktyka teoretyczna” nr 2-3.

Rousseau J.J. (1955), Emil, czyli o wychowaniu. Ossolineum, Warszawa.

Rousseau J.J. (1967), Przechadzki samotnego marzyciela. Warszawa, Czytelnik. 
Rousseau J.J.(1956), Wyznania. Warszawa, PIW.

Rousseau J.J. (1966), Umowa spoteczna. Warszawa, PWN.

Śniedziewski P. (2011), Melancholijne spojrzenie. Kraków, UNIVERITAS.

Środa M.(2003), Indywidualizm i jego krytycy. Warszawa, Aletheia.

Taylor Ch. (2001), Źródła podmiotowości. Narodziny nowoczesnej tożsamości. Warszawa, PWN.

Wollstonecraft M. (2011), Wolanie o prawa kobiety. Kraków, Mamania. 